\title{
The contribution of genre awareness and reading habits towards students' reading comprehension
}

\author{
Sri Andreani, Siti Muniroh*, Suharyadi, Utari Praba Astuti, and Yulizar \\ English Language Education Study Program, Faculty of Letters, \\ Universitas Negeri Malang, Jalan Semarang No. 5 Malang, East Java, Indonesia
}

\begin{abstract}
Previous studies revealed that genre awareness and reading habits partially correlate with reading comprehension. This article reported the results of a study aiming to find out the contribution of genre awareness and reading habits towards the development of students' comprehension of reading English texts. The participants of this study were 68 students of the Department of English of a state-owned university in East Java, Indonesia, in the 2020/2021 academic year. These students took the three reading courses (Intensive Course, Basic, and Intermediate Reading courses) and were assumed to have been familiar with genres and have developed some reading habits. This research employed a correlational design, involving two predicting variables (genre awareness and reading habits), and one response variable (comprehension). The data were gathered using three instruments: an objective test to measure students' genre awareness, an online questionnaire to identify students' reading habits, and an objective test to measure students' reading comprehension. The data were analyzed using multiple linear regression analysis aided by SPSS/PASW Program. The results showed that the data are normally distributed so that conclusions can be drawn accurately that genre awareness and reading habits partially and significantly contribute to reading comprehension. The results also indicated that genre awareness and reading habits simultaneously and significantly contribute to reading comprehension, as shown by the results of the analysis that genre awareness and reading habits contributed 0.203 or $20.3 \%$ to reading comprehension. The rest $(79.7 \%)$ was attributed to other variables outside the variables under study. This study concludes that good genre awareness and good reading habits help students develop good reading comprehension. The results provided in this paper can be used by English teachers as an alternative to help their students improve their genre awareness and cultivate good reading habits.
\end{abstract}

Keywords: EFL; genre awareness; Indonesia; reading comprehension; reading habit

\begin{tabular}{|c|c|c|}
\hline $\begin{array}{l}\text { First Received: } \\
19 \text { March } 2021 \\
\text { Final Proof Received } \\
\text { 19 September } 2021\end{array}$ & $\begin{array}{c}\text { Revised: } \\
\text { 4 June } 2021\end{array}$ & $\begin{array}{r}\text { Accepted: } \\
\text { 19 July } 2021 \\
\text { Published: } \\
\text { 30 September } 2021\end{array}$ \\
\hline $\begin{array}{l}\text { How to cite (in APA style): } \\
\text { Andreani, S., Muniroh, S., Suharya } \\
\text { awareness and reading habits } \\
\text { Journal of Applied Linguistic. }\end{array}$ & $\begin{array}{l}\text { tuti, U. P., Yu } \\
\text { ds students' r } \\
\text { ), 463-476. h }\end{array}$ & $\begin{array}{l}\text { 2021). The contribution of genre } \\
\text { comprehension. Indonesian } \\
\text { oi.org/10.17509/ijal.v11i2.35260 }\end{array}$ \\
\hline
\end{tabular}

\section{INTRODUCTION}

This study reported in this article focused on explaining how students' genre awareness and reading habits contribute to the development of their comprehension of reading English texts. In the literature, the genre has been popular in various fields, including in English language teaching. In general, there are two meanings of the genre (Suharyadi, 2021). The first meaning deals with the genre as a classification system of academic and non-academic works, either oral or written, in various disciplines. The second meaning refers to the idea that genre is a social activity. The latter notion is closely associated with the three existing

\footnotetext{
*Corresponding Author

Email: siti.muniroh.fs@um.ac.id
} 
schools of genres: The Sydney School, The ESP School, and The New Rhetoric School (see Hyon, 1996 for further details on these three genre schools). The Sydney School sees genres as "staged, goal-oriented, purposeful social processes" (Martin, 1992 , p. 505). Genres are staged because they are organised through stages in order to achieve their purposes; they are goal-oriented because they are used to make things done, and they are social because people interact through them (Martin 1992). The ESP school views genres within three components: communicative events, communicative purposes, and discourse community (Swales, 1990). Meanwhile, The New Rhetoric School looks at genres in terms of the recurrent situations and rhetorical practices (Miller, 1984). Although these three schools examine genres from different perspectives, they agree that genres cannot be separated from society in the production of language.

Understanding the concept of genres, whatever the school, is an important part of genre awareness. Genre awareness is not only "about a text type mastery, but also the ability to act and contribute in relevant ways in a discourse community" (Eriksson \& Gustafsson, 2008, p. 123). Genre awareness goes beyond this, as it "takes into account the targeted audience, the communicative purpose of the discourse, and the conventions socially constructed by the discourse community" (Rowley-Jolivet \& Carter-Thomas, 2005, p. 42). When students develop genre awareness, they gain insight into how a given genre fulfils a rhetorical purpose; how the various components of a text, the writer, the intended reader, and the text itself, are guided by purpose; and how they are apprenticed and function in their discourse communities. Further, Devitt (2004) states that genre awareness involves critical consciousness of both rhetorical purposes and ideological effects of generic forms. In this way, students gain an understanding of genre wherein they analyze generic conventions not only rhetorically, but culturally as well in order to interpret them. Thus, genre awareness can be used as a tool that enables students to approach the genre from the perspectives of lexicogrammar and beyond. Without genre awareness, students will not understand how the text works to fulfil its purpose, and when they encounter a new genre in another course, they may experience difficulties engaging with the text effectively.

This study also verified the influence of students' reading habits on their reading comprehension. Previous studies on reading habits in Indonesian EFL contexts have been centering on elements that are significant for students' reading comprehension. On one hand, Sakinah (2018) investigates the correlation between the four aspects of reading habits (reading material, frequency of reading, time spent in reading, and purpose of reading) to reading comprehension. Sakinah's suggests a partial correlation between students reading habits and reading achievement, as only reading materials and purposes of reading correlate with reading achievement; while the frequency of reading and time spent in reading has a low correlation with reading achievement. On the other hand, Wahyudi (2016) shows that there is no significant correlation between reading habits and reading comprehension, due to three factors: 1) the misperception of the students toward good reading habits, 2) students preferred to read for pleasure (comics, newspapers, sports magazines), and 3) the students preferred to read for pleasure, while the tests of this research were taken from reading for academic purpose materials. The contradictory findings reported by Sakinah (2018) and Wahyudi (2016) show the void in the research literature about the relationship between reading habit and reading comprehension. Similarly, Mu'awana (2018) and Parmawati (2018) found that there is a low correlation between the two variables. This incongruity needs further investigation; therefore, this study intends to fulfil this gap while adding another variable, namely genre awareness.

\section{Genre awareness}

The notion of genre assumed in this article is derived from rhetorical genre theory, which defines genre not simply in terms of the formal features of a text (the social function, the generic structure, and the language features) but also the actions within the text. The actions people/individuals do contain two elements: situation and motive. Hyland defines genre as "a term for grouping texts together, representing how writers typically use language to respond to recurring situations" (2003, p. 543). Genre in reading can be seen as the classification of written works based on the purpose, organization, and language use. Many genres are easily recognized, and we can readily understand their function because they are part of our everyday world. Academic genres, however, are often unfamiliar to students. Therefore, learning genres has already taken an important position in the teaching of English in Indonesia and students are exposed to English in different genres (Rozimela, 2014; Sari, 2017). Students, then, are facilitated with knowledge of generic and lexico-grammar features of several text types through which they learn shared formal characteristics of genres. It is believed that genre awareness makes it easy for students to deal with English texts as they understand the intricate connections between contexts and forms, to perceive potential ideological effects of genres, and to discern both constraints and choices that genres make possible (Devitt, 2004; Swales, 2009).

Genre awareness also refers to the knowledge of text structures within specific contexts and understanding of their typical linguistic or language 
features (Galea, 2005). The awareness makes reading in a specific context much easier (Karbelaei \& Hajezi, 2015; To \& Pang, 2019). Genre awareness is often connected to a reading strategy or a set of reading strategies (Grabe, 2012), as it helps readers to implement appropriate strategies in facing difficulties in their reading. Good readers learn to develop a strategy to recognize specific features of genres that are relevant to their needs and goals (Hansen, 2018). Yayli (2011) and Sari (2017) indicated that knowledge of the genre contributes to a better understanding of locating key information in texts. Their findings also revealed that knowledge of the organization of a particular text and common textual signals can help identify important information as well as the relationship between ideas in the text. Knowledge of genre can also improve readers' reading speed and increase confidence and enjoyment.

Andriyani et al. (2019) recommend that teachers develop students' genre awareness by introducing stages and phases of genres or conventions of genres and by providing linguistic resources that the students need to grasp. Genre awareness equips students with an understanding of components of texts, and this knowledge can be used to approach diverse texts to find implicit and explicit information and therefore, it can assist students' understanding of the texts. Literature in the field has seen that genre awareness and reading comprehension skills are correlated (Kalali \& Pishkar, 2015; Nam, 2014; Rozimela, 2014). Rozimela (2014) reveals that there is a correlation between genre awareness and reading comprehension, which means that students with good genre awareness had good reading comprehension and vice versa. Similarly, Kalali and Pishkar (2015) find that awareness of genre can improve students' reading comprehension. Some other studies also confirm the contribution of genre awareness to students' reading comprehension without mentioning the extent to which genre awareness can aid reading comprehension (Molotja \& Themane, 2018; Sari, 2017; Sawangsamutchai \& Rattanavich, 2016; Xu \& Li, 2018; Yayli, 2011). The significant role of genre awareness on students' reading comprehension is emphasized by Sari (2017), who conducted a study on university students as she found that students who were not aware of genres had problems in reading comprehension.

Acknowledging the important role of genre awareness, teachers have attempted to improve their knowledge of generic and lexicogrammar features of different text types through which they learn shared formal characteristics of genres. Galea (2005) states that teachers need to learn to develop discourse-based materials to make the students aware that linguistic patterns exist across stretches of text with various purposes. It is believed that genre awareness enables students to read English at ease (Devitt, 2004). To measure the students' genre awareness, we need to know its elements, namely (1) topic of the text, (2) speaker/author of the text, (3) audience for the text, (4) relationship between the participants, (5) purpose of the text, (6) setting, (7) structure of the text, (8) tone of the text, (9) typical patterns of grammar, (10) typical vocabulary, (11) community expectations and/or shared understandings, and (12) assumed background knowledge (Anderson \& Anderson, 2003; Vollmer, 2018). Besides genre awareness, reading comprehension also has some other determinant factors, i.e., background knowledge about the content of the texts, specific vocabulary used in a text, and strategies of reading a text (Rozimela, 2014; Sari, 2017) that can develop reading habits.

\section{Reading habits}

Neal et al. (2006) view reading habits as a way of how readers organize their reading and how often, how much, and what they read. Further, reading habit functions as automatic and unconscious processes that are involved in constructing meaning from text (Zwiers, 2004). Such processes do not need much concentration and attention so that they assist people in doing actions immediately, as habits can go on while people think about or pay attention to other things. Reading habits are often considered in terms of the number of materials being read, the frequency of reading as well as the average time spent on reading (Chettri \& Rout, 2013). Chettri and Rout also mention that students' interest in fiction and non-fiction become one of the factors influencing students reading habits. Reading habits enrich students' vocabulary and hence help them in reading. Students with good reading habits can easily understand reading materials as they enable them to predict the content of a passage correctly (Andriyani et al., 2019). Put in another way, if students have poor reading habits, then their reading comprehension would be poor. Thus, cultivating good reading habits is essential for better reading comprehension.

Although habits are generally associated with unconscious activities, they can be developed through the repetition of an activity that is done in the same way and is well-planned (Iskandar \& Sunendar, 2017). This means that when people plan an activity well and do it consciously, new patterns will be formed internally. In this way, habits, whether good or bad, will stay within their consciousness and are saved in one pattern in their life. Gaona (2011, pp. 59-60) identifies six elements of reading habits, namely (1) the frequency of reading in one's spare time, (2) the number of books read, (3) the time spent on academic reading, (4) the time spent on non-academic reading, (5) the motivation in the family environment as indicated 
by the recommended book purchased by the family, and (6) the motivation in the academic environment. Reading habit is also shaped by external factors such as culture, learning quality, tendency in talking, availability of interesting electric media and reading materials (Iskandar \& Sunendar, 2017).

Students' reading comprehension can be significantly achieved if they have good reading habits. A study on the correlation between reading habit and reading comprehension revealed that students with good reading habits had better reading comprehension. This finding is supported by Rustania et al. (2019) who found that there was a positive and significant contribution of the students' reading habits towards their reading comprehension. A similar study conducted by Andriyani et al. (2019) showed that there was a significant correlation between reading habits in English and reading comprehension. This finding is supported by Hidayah's (2014) who revealed that both variables were correlated. In relation to this, Wulandari (2016) indicated that students who did not have good reading habits had low reading comprehension. Another study by Muawanah (2014) also discovered that reading habits significantly influenced students' reading achievement. Thus, reading habits have been acknowledged scientifically as one of the factors that determine the success of students' reading comprehension.

\section{Reading comprehension}

Reading comprehension is usually understood as the process by which a person understands the meaning of written language. The reading comprehension courses offered in the research site, Department of English, Universitas Negeri Malang, deal with understanding, remembering, or recalling the information explicitly stated in a text and finding information stated implicitly in the text using experience, intuition, and inference. Following Longman dictionary of applied linguistics (Richards et al., 1985) reading comprehension in this paper refers to literal comprehension and inferential comprehension.

To be efficient readers and to improve reading comprehension, students need to develop several strategies. Brown (2001) identifies a number of reading strategies, including skimming a text for main ideas, scanning a text for specific information, using mapping or clustering, guessing (meaning, grammatical relationship, discourse relationship, cultural reference, and content messages), analyzing vocabulary, distinguishing between literal and implied meanings, using discourse markers to process relationships. In this study, the student's reading comprehension is evaluated through their ability to use the strategies in deducing the general topic, main idea or major points; identifying important facts and details, finding vocabulary meaning in context, identifying pronoun references, and making inferences about what is implied in a passage.

As stated previously, studies have confirmed the correlation between genre awareness and reading comprehension, and reading habit with reading comprehension achievement. However, information about the contribution of both genre awareness and reading habits to reading comprehension in the EFL contexts seems to be minimally provided. Therefore, this article aims to verify the contribution of genre awareness and reading habit both partially and simultaneously towards students' reading comprehension and the extent to which these two variables contribute to reading comprehension. Specifically, the article is geared towards the following questions:

1. Do genre awareness and reading habits partially contribute to reading comprehension?

2. Do genre awareness and reading habits simultaneously contribute to reading comprehension?

3. To what extent do genre awareness and reading habits contribute to students' reading comprehension?

\section{METHOD \\ Design and participants}

A correlational design involving two predictor variables (genre awareness and reading habits) and one response variable (reading comprehension) was deployed. Sixty-eight students of the Department of English, Universitas Negeri Malang, were selected purposely as the participants in the study. They were chosen because they had the same characteristics. They had taken Intensive Course-Reading course, Basic Reading course and were taking Intermediate Reading course in the first semester of the 2019/2020 academic year, when the data were collected. By taking those three courses, it was assumed that they have learned several text types from which they developed genre awareness. These text types include information report, recount, discussion, exposition, and explanation. There are three instruments used in this study: (1) a test of genre awareness, (2) a reading habit questionnaire, and (3) a reading comprehension test. The data were analyzed using multiple linear regression analysis aided by SPSS/PASW Program.

\section{Genre awareness test}

The first instrument is to measure the first predictor variable $\left(\mathrm{X}_{1}\right)$, namely the students' genre awareness. The test was developed based on elements of genre awareness proposed by Vollmer (2018), which consist of 11 aspects of genres: (1) author of the text, (2) audience of the text, (3) relationship between the participants, (4) purpose of the text, (5) 
setting, (6) structure of the text, (7) tone of the text, (8) typical patterns of grammar, (9) typical vocabulary, (10) community expectation and/or shared understandings, and (11) assumed background knowledge. The test of genre awareness covered all these aspects, except for numbers 1 and 4 as these two aspects were covered in the reading comprehension test. The reading passages for the genre awareness test were selected from TOEFL Preparation materials. The TOEFL Preparation reading passages were used for two reasons: they represent the text types the students learned in the three reading courses and they are well-structured. Originally, these passages were quite long, so they were adapted to make them shorter while the ideas were left intact. In this way, within one administration, the test has enough room to assess the students' awareness of the five text types and the 11 aspects characterizing each. The adaption resulted in five passages ranging between 280 and 349 words in length. Each of the reading passages was followed by 7-9 multiple choice questions, with four options $(a, b, c$, and $d)$. The passages and the corresponding questions were converted into a Google Form so that students could do the test online. Forty questions were developed from these passages, concerning the genre of the passages, the author, the audience, the purpose, the setting, the structure, the tone, the grammatical patterns, the vocabulary, shared understanding, background knowledge (Vollmer, 2018). These questions were scrutinized by two validators who found that there were three language errors in one of the passages and in two of the question stems. After the revision as suggested by the reviewer, the test was used as the instrument for data gathering. Table 1 presents the outline of the final version of the genre awareness test.

Table 1

Outline of the Genre Awareness Test

\begin{tabular}{|c|c|c|c|}
\hline Variable & Aspects & Total number & Item umber \\
\hline Genre awareness & 1. author of the text & 3 & $2 / 19 / 26$ \\
\hline \multirow[t]{11}{*}{$\left(\mathrm{X}_{1}\right)$} & 2. audience of the text & 1 & 11 \\
\hline & 3. purpose of the text & 6 & $1 / 8 / 10 / 18 / 25 / 33$ \\
\hline & 4. setting & 5 & $3 / 12$ / $20 / 27 / 34$ \\
\hline & 5. structure of the text & 3 & $9 / 32 / 40$ \\
\hline & 6. tone of the text & 3 & $6 / 23 / 39$ \\
\hline & 7. typical patterns of grammar & 4 & $4 / 14 / 28 / 35$ \\
\hline & 8. typical vocabulary & 5 & $13 / 21 / 30 / 36 / 37$ \\
\hline & 9. community expectation and/or shared understandings & 1 & 17 \\
\hline & 10. assumed background knowledge & 4 & $5 / 15 / 22 / 29$ \\
\hline & 11. genre & 5 & $7 / 16 / 24 / 31 / 38$ \\
\hline & The overall number of items & 40 & \\
\hline
\end{tabular}

\section{Reading habit questionnaires}

The second instrument is intended to measure the second predictor variable $\left(\mathrm{X}_{2}\right)$, the students' reading habits. This instrument adapted Gaona's (2011) elements by combining motivation in the family environment and the academic environment into "why you read", combining the frequency of reading and time spent on reading into "how much time spent on reading", adding one element ("how you read"), and adding questions relevant to each element. This adaptation resulted in twenty-six questions that cover four aspects of good English reading habits, i.e. (1) what they read, (2) why they read, (3) how they read, and (4) how much time they spent on reading English. There are eight questions for the first aspect, four questions for the second aspect, ten questions for the third aspect, and four questions for the fourth aspect. Each stem in these aspects is in the form of a statement about an activity reflecting a good reading habit, for example, I question and evaluate the content of what I read, as I read. Table 2 presents the outline of the reading habit questionnaire. The item numbers refer to the numbers of the items in the final version of the questionnaire.

Table 2

Outline of Reading Habit Questionnaires

\begin{tabular}{llrl}
\hline \multicolumn{1}{c}{ Variable } & \multicolumn{1}{c}{ Aspects } & Total Number & \multicolumn{1}{c}{ Item Number } \\
\hline Reading & 1. What you read & 8 & $1 / 2 / 3 / 4 / 5 / 6 / 7 / 8$ \\
Habit $\left(\mathrm{X}_{2}\right)$ & 2. Why you read & 4 & $9 / 10 / 11 / 12$ \\
& 3. How you read & 10 & $13 / 14 / 15 / 16 / 17 / 18 / 19 / 20 / 21 / 22$ \\
& 4. How much time you spend reading English & 4 & $23 / 24 / 25 / 26$ \\
\hline & Overall number of items & $\mathbf{2 6}$ & \\
\hline
\end{tabular}

Items number 1-26 is provided with a fouroption Likert-Scale ("never", "rarely", "sometimes", and "often"). These options are labelled 1 (poor), 2 (average), 3 (good), and 4 (very good) in terms of reading habits. The underlying assumption is that the more often they perform the activities, the better 
their English reading habits would be. The reading habit questionnaire was validated by two experts and revised by the researchers before it was used for collecting the data. The revisions include the reformulation of the stem to make it clear to the respondents that the questionnaire mainly refers to English reading habits, the reformulation of the options to make them parallel, and the omission of items that cannot possibly go through statistical analysis. It was then converted into Google Form and distributed online to the students.

\section{Reading comprehension test}

The reading comprehension test was deployed to measure the response variable (Y), the students' ability to (1) deduce the topic, main idea or major points, (2) identify important facts and details, (3) understand the meaning of vocabulary in context, (4) identify pronoun referents, and (5) make inferences about what is implied in a passage. The first draft of the reading test was selected and adapted from TOEFL Preparation Test materials. There were thirty-five questions in the reading comprehension test. The draft of the test was examined by two experts and, then, was revised based on the feedbacks of the validator. The revisions include paraphrasing the instruction, diction, misspelling, grammatical errors, the formulation of the options, and level of difficulty. Table 3 presents the outline of the Reading Comprehension Test. The numbers of the test items follow those in the final version of the test. The reading comprehension test was also converted into Google Form and distributed online.

Table 3

Blueprint of the Reading Comprehension Test

\begin{tabular}{clcc}
\hline \multicolumn{1}{c}{ Variable } & \multicolumn{1}{c}{ Indicators } & Total number & \multicolumn{1}{c}{ Item Number } \\
\hline $\begin{array}{c}\text { Reading } \\
\begin{array}{c}\text { Comprehension } \\
\text { (Y) }\end{array}\end{array}$ & a. $\begin{array}{l}\text { Deducing the general topic, main idea or } \\
\text { major points }\end{array}$ & 3 & $8 / 20 / 27$ \\
& b. Identifying important facts and details & 15 & $\begin{array}{l}1 / 3 / 4 / 5 / 6 / 13 / 14 / 16 / 17 \\
/ 18 / 24 / 29 / 31 / 34 / 35\end{array}$ \\
& c. $\begin{array}{l}\text { Getting the meaning of vocabulary in } \\
\text { context }\end{array}$ & 6 & $2 / 11 / 15 / 25 / 30 / 33$ \\
& $\begin{array}{l}\text { d. Identifying pronoun referents } \\
\text { e. Making inferences about what is implied } \\
\text { in a passage }\end{array}$ & 3 & $9 / 21 / 28$ \\
$\quad$ The overall number of items & 8 & $7 / 10 / 12 / 19 / 22 / 23 / 26 /$ \\
& $\quad 35$ & \\
\hline
\end{tabular}

\section{Data analysis}

The data analysis was conducted in two stages, namely scoring the participants' responses on the three tests and performing statistical analysis using multiple linear regression analysis. In the first stage, the students' responses on genre awareness test were calculated using this formula:

$$
\text { Score }=\frac{\text { number of correct answers }}{40} \times 100
$$

Then, the students' responses on the reading comprehension test were calculated using the following formula:

$$
\text { Score }=\frac{\text { number of correct answers }}{35} \times 100
$$

Finally, the students' responses on the reading habit questionnaire were calculated using the formula below:

Note:

$$
\text { Score }=\frac{1 \times n 1+2 \times n 2+3 \times n 3+4 \times n 4}{\operatorname{maxscore}}
$$

$\mathrm{n} 1=$ number of "never" answers

$\mathrm{n} 2=$ number of "rarely" answers

n3 = number of "sometimes" answers

$\mathrm{n} 4$ = number of "often" answers

$\max$ score $=26$ items $\mathrm{x} 4$

In the reading habit test, a score was assigned to each of the student's answer ( 1 for “never", 2 for "rarely", 3 for "sometimes", and 4 for "often" $O R 1$ for the shortest range of time and 4 for the longest one).

Before performing the statistical analysis, the normality test was conducted to check whether the dependent variable is normally distributed within each group. Ghasemi and Zahediasl (2012) write that statistical procedures for correlational study and t-test are done based on assumption that the data follow a normal distribution, to ensure an accurate and reliable conclusion from the finding. It is preferable that normality is assessed both visually and through normality tests, such as KolmogorovSmirnov (K-S) test, Lilliefors corrected K-S test, Shapiro-Wilk test, and Anderson-Darling test (Ghasemi \& Zahediasl, 2012). Further, Ghasemi and Zahediasl (2012) emphasize that the Shapiro-Wilk test provides better power than the K-S test even after the Lilliefors correction, due to its ability to detect whether a sample comes from a non-normal distribution, and based on this recommendation, the Shapiro-Wilk test, provided by the SPSS software, was employed in this study, prior to multiple -linear regression analysis.

The multiple linear regression analysis was done using SPSS/PASW Program, involving genre awareness $\left(\mathrm{X}_{1}\right)$ and reading habits $\left(\mathrm{X}_{2}\right)$ as the predictor variables and reading comprehension as 
the response variable (Y), which involved three tests:

1. T-test to find whether genre awareness and reading habits partially contribute to reading comprehension.

2. F-test to find whether genre awareness and reading habits simultaneously contribute to reading comprehension

3. $\mathrm{R}^{2}$-test to find how far genre awareness and reading habits contribute to reading comprehension

The hypotheses testing was done at an alpha level of .05 .

\section{Null-hypotheses}

Ho1: There is no significant contribution of reading comprehension by genre awareness and reading habits

Ho2a: In the presence of the others, there is no significant contribution of reading comprehension by genre awareness

Ho2b: In the presence of the others, there is no significant contribution of reading comprehension by reading habits

\section{Alternative hypotheses}

Table 4

The Result of the Normality Test

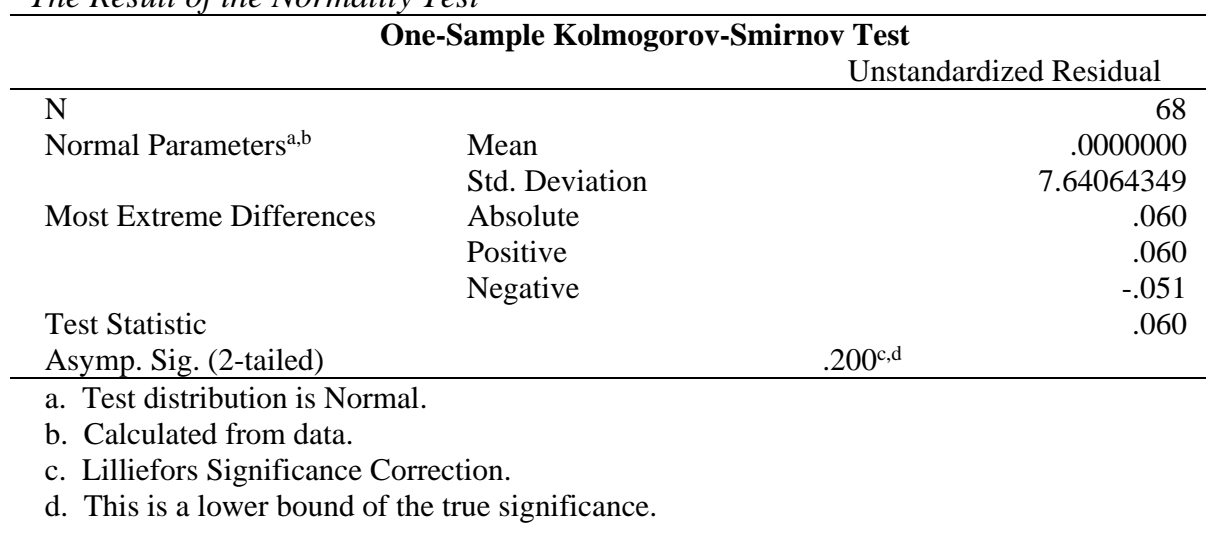

The following sections present: (1) the partial contribution of genre awareness and reading habits to reading comprehension, (2) the simultaneous contribution of genre awareness and reading habits to reading comprehension, (3) the extent of the contribution of genre awareness and reading habits to reading comprehension, and (4) other findings.

The partial contribution of genre awareness and reading habits to reading comprehension

To determine the partial contribution of genre awareness and reading habits to reading comprehension, a t-test was conducted and yields the following result (see Table 5).
Hi1: There is a significant contribution of reading comprehension by genre awareness and reading habits

Hi2a: In the presence of the others, there is a significant contribution of reading comprehension by genre awareness

Hi2b: In the presence of the others, there is a significant contribution of reading comprehension by reading habits

\section{FINDINGS}

This section is geared towards the findings of the study; mainly dealing with results of statistical analysis concerning the contribution of genre awareness and reading habits towards reading comprehension. It begins by presenting the result of the normality test; followed by results regarding the contribution of genre awareness and reading habits.

The result of the normality test indicated that all the data were normally distributed. The output table of the SPSS One-Sample KolmogorovSmirnov Test shows that the significance value (Sig.) of all the variables is 0.200 . Sig. $0.200>0.05$, which indicates that all the data are normally distributed. Thus, the conclusions of this study can be drawn accurately from the result of the multiple linear regression analysis (see Table 4).
The output table of the SPSS Coefficient shows that the Sig. value of the Genre Awareness variable is 0.007 . Sig. $0.007<0.05$ indicates that the null hypothesis $\left(\mathrm{H}_{\mathrm{o}} 2 \mathrm{a}\right)$ is rejected and the alternative hypothesis $\left(\mathrm{H}_{\mathrm{i}} 2 \mathrm{a}\right)$ is accepted.

As for the reading habits, the Sig. value is 0.008. Sig. $0.008<0.05$ means that, again, the null hypothesis $\left(\mathrm{H}_{\mathrm{o}} 2 \mathrm{~b}\right)$ is rejected and the alternative hypothesis $\left(\mathrm{H}_{\mathrm{i}} 2 \mathrm{~b}\right)$ is accepted. This can be interpreted that in the presence of others, there is a significant contribution of reading comprehension by reading habits. Therefore, it can be concluded that variables genre awareness and reading habits partially and significantly contribute to reading comprehension. 
Table 5

The Result of the T-Test

\begin{tabular}{|c|c|c|c|c|c|c|}
\hline \multicolumn{7}{|c|}{ Coefficients $^{\mathbf{a}}$} \\
\hline & \multirow{2}{*}{ Model } & \multicolumn{2}{|c|}{ Unstandardized Coefficients } & \multirow{2}{*}{$\begin{array}{c}\text { Standardized Coefficients } \\
\text { Beta }\end{array}$} & \multirow{2}{*}{$\mathbf{t}$} & \multirow{2}{*}{ Sig } \\
\hline & & B & Std. Error & & & \\
\hline \multirow{3}{*}{1} & (Constant) & 31.059 & 11.614 & & 2.674 & .009 \\
\hline & $\begin{array}{l}\text { Genre } \\
\text { Awareness }\end{array}$ & .362 & .129 & .311 & 2.800 & .007 \\
\hline & Reading Habit & .253 & .092 & .304 & 2.739 & .008 \\
\hline
\end{tabular}

a. Dependent Variable: Reading Comprehension

The simultaneous contribution of genre awareness and reading habits to reading comprehension

The simultaneous contribution of genre awareness and reading habits to reading comprehension was identified through an f-test. The result of the f-test is presented in Table 6.

The output table of SPSS ANOVA shows the f-test points at a significance value of 0.001 . Sig. $0.001<0.05$ indicates that the null hypothesis $\left(\mathrm{H}_{0} 1\right)$ is rejected and the alternative hypothesis $\left(\mathrm{H}_{\mathrm{i}} 1\right)$ is accepted. Thus, there is a significant contribution of reading comprehension by genre awareness and reading habits. From this, it can be interpreted that genre awareness and reading habits simultaneously and significantly contribute to reading comprehension.

The extent of the contribution of genre awareness and reading habits to reading comprehension

The extent of the contribution of genre awareness and reading habits to reading comprehension is identified through an $\mathrm{R}^{2}$-test. The result of this test is presented in Table 7.

Table 6

The Result of the F-Test

\begin{tabular}{|c|c|c|c|c|c|c|}
\hline \multicolumn{7}{|c|}{ ANOVA $^{a}$} \\
\hline & Model & Sum of Squares & df & Mean Square & $\mathbf{F}$ & Sig. \\
\hline \multirow{3}{*}{1} & Regression & 996.665 & 2 & 498.333 & 8.281 & $.001^{\mathrm{b}}$ \\
\hline & Residual & 3911.422 & 65 & 60.176 & & \\
\hline & Total & 4908.087 & 67 & & & \\
\hline
\end{tabular}

a. Dependent Variable: Reading Comprehension

b. Predictors: (Constant), Reading Habit, Genre Awareness

Table 7

$R^{2}$-test

\begin{tabular}{ccccc}
\hline & \multicolumn{3}{c}{ Model Summary } \\
\hline Model & $\mathrm{R}$ & $\mathrm{R}$ Square & Adjusted R Square & Std. Error of the Estimate \\
1 & $.451^{\mathrm{a}}$ & .203 & .179 & 7.75730 \\
\hline a. Predictors: (Constant), Reading Habit, Genre Awareness
\end{tabular}

a. Predictors: (Constant), Reading Habit, Genre Awareness

The output table of the SPSS Model Summary above shows that the value of $R^{2}$ is 0.203 or $20.3 \%$. This means that genre awareness and reading habits simultaneously contribute to reading comprehension to the extent of 0.203 or $20.3 \%$. The rest $(79.7 \%)$ is contributed by other variables outside the regression equation or outside the variable under study. Analysis was also conducted to find the contribution of each aspect of students' genre awareness and reading habits towards their reading comprehension.

The contribution of each aspect of genre awareness to reading comprehension

The contribution of each aspect of genre awareness to reading comprehension is shown in Table 8 .

According to the output table of SPSS Coefficients in Table 8, the significance (Sig.) values of the author of the text (0.836), audience $(0.273)$, the purpose of the text $(0.117)$, setting
(0.076), the structure of the text $(0.537)$, tone of text (0.110), typical patterns of grammar (0.385), assumed background knowledge (0.500), and genre (0.192) are above the significance level of 0.05 . Thus, these aspects of genre awareness do not have a partial contribution towards reading comprehension. On the other hand, the significance (Sig.) values of typical vocabulary (0.041), community expectation and/or shared understandings (0.014) are below 0.05. This indicates that typical vocabulary and community expectation and/or shared understandings contribute partially to reading comprehension.

Table 9 shows the simultaneous contribution of the aspects of genre awareness to reading comprehension. This output table of SPSS ANOVA shows a significance (Sig.) value of 0.002. Sig. $0.002<0.005$ indicate that author of text, audience, the purpose of the text, setting, the structure of the text, the tone of the text, typical patterns of 
grammar, typical vocabulary, community expectation and/or shared understandings, assumed background knowledge, dan genre contribute simultaneously to reading comprehension.
Table 10 presents the extent to which the aspects of genre awareness contribute to reading comprehension.

Table 8

The Result of the T-Test on the Contribution of Each Aspect of Genre Awareness to Reading Comprehension

\begin{tabular}{|c|c|c|c|c|c|c|}
\hline \multicolumn{7}{|c|}{ Coefficients $^{\mathrm{a}}$} \\
\hline & \multirow[t]{2}{*}{ Model } & \multicolumn{2}{|c|}{$\begin{array}{c}\text { Unstandardized } \\
\text { Coefficients }\end{array}$} & \multirow{2}{*}{$\begin{array}{c}\begin{array}{c}\text { Standardized } \\
\text { Coefficients }\end{array} \\
\text { Beta } \\
\end{array}$} & \multirow[t]{2}{*}{$\mathbf{t}$} & \multirow[t]{2}{*}{ Sig. } \\
\hline & & B & Std. Error & & & \\
\hline \multirow[t]{12}{*}{1} & (Constant) & 61.630 & 11.680 & & 5.276 & .000 \\
\hline & Author of Text & -.131 & .630 & -.025 & -.208 & .836 \\
\hline & Audience & .909 & .820 & .129 & 1.108 & .273 \\
\hline & Purpose of Text & .577 & .362 & .182 & 1.593 & .117 \\
\hline & Setting & -.777 & .430 & -.199 & -1.809 & .076 \\
\hline & Structure of Text & .350 & .563 & .068 & .621 & .537 \\
\hline & Tone of Text & 1.098 & .676 & .203 & 1.625 & .110 \\
\hline & Typical Patterns of Grammar & -.472 & .539 & -.108 & -.875 & .385 \\
\hline & Typical Vocabulary & .797 & .381 & .257 & 2.093 & .041 \\
\hline & $\begin{array}{l}\text { Community Expectation and/or } \\
\text { Shared Understandings }\end{array}$ & 2.335 & .917 & .285 & 2.546 & .014 \\
\hline & Assumed Background Knowledge & -.587 & .865 & -.076 & -.679 & .500 \\
\hline & Genre & .874 & .662 & .162 & 1.320 & .192 \\
\hline
\end{tabular}

a. Dependent Variable: Reading Comprehension

Table 9

The Result of the F-Test on the Simultaneous Contribution of the Aspects of Genre Awareness to Reading Comprehension

\begin{tabular}{llccccc}
\hline & & \multicolumn{5}{c}{ ANOVA $^{\mathbf{a}}$} \\
\hline & Model & Sum of Squares & df & Mean Square & F & Sig. \\
\hline 1 & Regression & 1879.961 & 11 & 170.906 & 3.161 & $.002^{\mathrm{b}}$ \\
& Residual & 3028.127 & 56 & 54.074 & & \\
& Total & 4908.087 & 67 & & & \\
\hline
\end{tabular}

a. Dependent Variable: Reading Comprehension

b. Predictors: (Constant), Genre, Setting, Community Expectation and/or Shared Understandings, Audience, Structure of Text, Purpose of Text, Author of Text, Assumed Background Knowledge, Typical Patterns of Grammar, Typical Vocabulary, Tone of Text

Table 10

The Result of the $R^{2}$-test on the Extent to Which the Aspects of Genre Awareness Contribute to Reading Comprehension

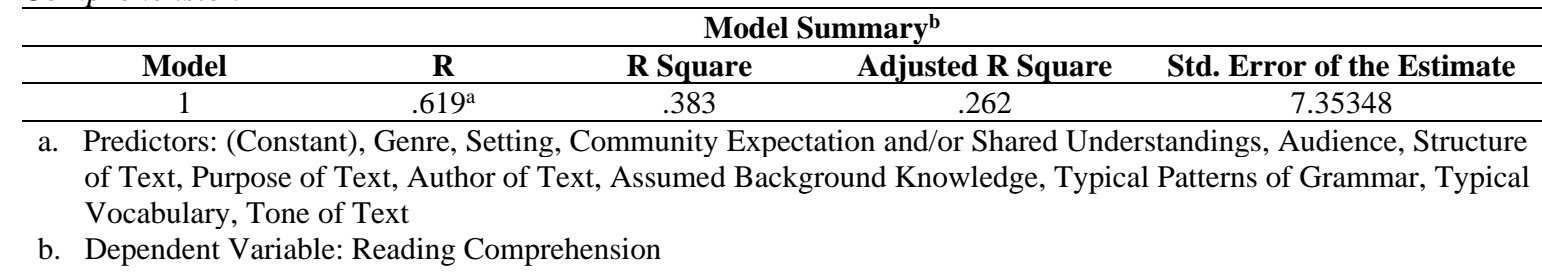

The output table of the SPSS Model Summary points at an $\mathrm{R}^{2}$ value of 0.383 or $38.3 \%$. This indicates the author of text, audience, the purpose of the text, setting, the structure of the text, the tone of the text, typical patterns of grammar, typical vocabulary, community expectation and/or shared understandings, assumed background knowledge, and genre have simultaneous contribution of $38.3 \%$ to reading comprehension. The rest $(61.7 \%)$ is contributed by factors outside the regression equation or outside the factors under study.
The contribution of each aspect of reading habits to reading comprehension

The contribution of each aspect of reading habits to reading comprehension is shown in Table 11.

The output table of SPSS Coefficients above shows the significance (Sig.) value of what the students read $(0.125)$, how often they read $(0.103)$, why they read (0.918), and how they read (0.666) are all above the level of significance of 0.05 . This means that none of them contributes partially to Reading Comprehension. Yet, the significance value of time spent is 0.035 which is lower than 0.05 and 
means that it partially contributes to reading comprehension.

Table 12 presents the simultaneous contribution of the aspects of reading habits to reading comprehension.

The output table of SPSS ANOVA above a significance (Sig.) value of 0.028 . Sig. $0.028<0.05$ indicates that what the students read, how often they read, why they read, how they read, dan the time spent on reading simultaneously contribute to reading comprehension. Table 13 shows how much these aspects contribute simultaneously to reading comprehension.

Table 11

The Result of the T-Test on the Contribution of Each Aspect of Reading Habits to Reading Comprehension

\begin{tabular}{|c|c|c|c|c|c|}
\hline \multicolumn{6}{|c|}{ Coefficients $^{\mathrm{a}}$} \\
\hline \multirow{2}{*}{ Model } & \multicolumn{2}{|c|}{ Unstandardized Coefficients } & \multirow{2}{*}{$\begin{array}{c}\text { Standardized } \\
\text { Coefficients }\end{array}$} & \multirow{2}{*}{$\mathbf{t}$} & \multirow{2}{*}{ Sig. } \\
\hline & $\mathbf{B}$ & Std. Error & & & \\
\hline (Constant) & 64.003 & 8.529 & & 7.504 & .000 \\
\hline What They Read & .545 & .434 & .208 & 1.254 & .215 \\
\hline How Often They Read & -3.479 & 2.104 & -.222 & -1.653 & .103 \\
\hline Why They Read & -.080 & .772 & -.016 & -.104 & .918 \\
\hline How They Read & .134 & .309 & .072 & .433 & .666 \\
\hline Time Spent on Reading & 1.288 & .599 & .314 & 2.151 & .035 \\
\hline
\end{tabular}

a. Dependent Variable: Reading Comprehension

Table 12

The result of the F-Test on the Simultaneous Contribution of the Aspects of Reading Habits on Reading Comprehension

\begin{tabular}{clccccc}
\hline \multicolumn{1}{c}{} & & \multicolumn{5}{c}{ ANOVA $^{\mathbf{a}}$} \\
\hline \multirow{2}{*}{1} & Model & Sum of Squares & df & Mean Square & F & Sig. \\
& Regression & 881.375 & 5 & 176.275 & 2.714 & $.028^{\mathrm{b}}$ \\
& Residual & 4026.713 & 62 & 64.947 & & \\
& Total & 4908.087 & 67 & & & \\
\hline
\end{tabular}

b. Predictors: (Constant), How Often They Read, What They Read, Time Spent on Reading, Why They Read, How They Read

Table 13

The result of the $R^{2}$-test on the Simultaneous Contribution of the Aspects of Reading Habits to Reading Comprehension

\begin{tabular}{ccccc}
\hline & \multicolumn{4}{c}{ Model Summary $^{\mathbf{b}}$} \\
\hline Model & R & R Square & Adjusted R Square & Std. Error of the Estimate \\
\hline 1 & $.424^{\mathrm{a}}$ & .180 & .113 & 8.05897 \\
\hline a. & Predictors: (Constant), How Often They Read, What They Read, Time Spent, Why They Read, How They Read
\end{tabular}

b. Dependent Variable: Reading Comprehension

The output table of SPSS Model Summary shows an $\mathrm{R}^{2}$ of 0.180 or $18 \%$, which means that what the students read, how often they read, why they read, how they read, dan time spent simultaneously contribute to reading comprehension to the extent of $18 \%$, leaving the rest of $82 \%$ to other factors that are outside the regression equation or outside the scope of this study.

\section{DISCUSSIONS}

This section shifts gear into the discussion of findings that have been presented in the previous section. In general, the result of the analysis shows that genre awareness and reading habits hold a significant contribution to reading comprehension both partially and simultaneously. The discussion of these findings is presented in three sections: (1) genre awareness and reading comprehension; (2) reading habits and reading comprehension; and (3) genre awareness, reading habits, and reading comprehension.

\section{Genre awareness and reading comprehension}

The finding concerning the partial contribution of genre awareness to reading comprehension confirms the results of the previous studies (e.g. from Andriyani et al., 2019; Azizah \& Fahriany, 2017; Grabe, 2012; Hansen, 2018; Kalali \& Pishkar, 2015; Karbelaei \& Hajezi, 2015; Molotja \& Themane, 2018; Nam, 2014; Rozimela, 2014; Sari, 2017; Sawangsamutchai \& Rattanavich, 2016; To \& Pang, 2019; Xu \& Li, 2018; Yayli, 2011). In general, these previous studies led to several findings. First, there is a correlation between genre awareness and reading comprehension. Second, students with good genre awareness have good reading comprehension. Third, genre awareness in reading can help students comprehend texts. Fourth, students who were not 
aware of genres had problems in reading comprehension.

All the research findings cited in this article point out that genre awareness contributes to reading comprehension. Yet, the findings of this study reveal that of all the aspects of genre awareness mentioned by Vollmer (2018), only two partially contribute to reading comprehension. As stated previously, Vollmer mentions 11 typical aspects of genre awareness, i.e., author of text, audience, the purpose of the text, setting, the structure of the text, the tone of the text, typical patterns of grammar, assumed background knowledge, genre, typical vocabulary, community expectation and/or shared understandings as the typical aspects of genre awareness. Of these aspects, only the last twotypical vocabulary and community expectation and/or shared understandings - show a partial contribution to reading comprehension. This is in line with Grabe's (2012) statement that the reading process involves, among others, vocabulary, yet it contradicts his statement about the importance of structural knowledge and content/world knowledge because in this study these two aspects are not found to have any partial contribution to reading comprehension.

Interestingly, even though genre awareness, in general, is found to have a partial contribution to reading comprehension, the finding of this study also reveals that knowledge of (type of) genre does not. In this way, this finding refutes Devitt's (2004) and Swales' (2009) statement that reading comprehension partly depends on the knowledge about genre. It also contradicts Toledo's (2005) argument that one who learns a language should have knowledge about genres in the language in order to obtain the purpose of communication successfully because this study finds that genre with the presence of other factors does not determine reading comprehension. In addition to this, the finding of this study also disproves Hyons' (2002) and Johns' (2008) assertion that knowledge about genres which includes awareness of their names, purposes, and language features is essential for effective reading and Francis' and Hallam's (2000) finding that students' reading comprehension is affected by their ability to deal with text genre.

It is also interesting to know that even though only two of the 11 aspects of genre awareness have a partial contribution to reading comprehension, these 11 aspects altogether have a simultaneous contribution to reading comprehension. The contribution, however, is relatively small, only $38.3 \%$, and this finding suggest that other factors that support students' reading comprehension need to be investigated, such as students' critical consciousness of both rhetorical purposes and ideological effects, which is suggested by Devitt (2004) as the component of genre awareness.

\section{Reading habits and reading comprehension}

The finding of this study shows that reading habits have a partial contribution to reading comprehension. This finding supports the results of the previous study (e.g. Suhana \& Haryudin, 2017) which reported that reading habits have a significant effect on reading comprehension. This study also yields other findings, concerning the aspects of reading habits, namely what the students read, how often they read, why they read, how they read, and time spent on reading. Of these four aspects, only the last one - the time spent on reading-shows a partial contribution towards reading comprehension. Chettri and Rout (2013) assert that habits of independent reading, or students choosing to read on their own time, are strong indicators of school and reading success and that students who achieved high scores on reading assessments, among other indicators of literacy learning, appeared to have a high intrinsic motivation to read, and often chose to read on a regular basis outside of school. These students prefer to spend their time reading, while their friends may spend their time on something else.

\section{Genre awareness, reading habits, and reading comprehension}

The new findings from this study that contribute to a knowledge development deal with the extent of students' genre awareness and reading habits contributed to students' reading comprehension. Genre awareness partially contributes to reading comprehension to the extent of $38.3 \%$; Reading habits partially contribute to reading comprehension to the extent of $18 \%$, and both genre awareness and reading habits simultaneously contribute to reading comprehension to the extent of $20.3 \%$. This indicates that there are other factors outside the regression equation and the scope of the study that affect reading comprehension. These factors include, among others, the knowledge of discourse and text structure (Taylor, 1985), the cognitive abilities (Trabasso, 1981), and the affective state (Garner, 1987) of the reader and the graphic, paralinguistic, linguistic, organizational characteristic of a text (Nuttal, 1982).

\section{CONCLUSION}

This article has presented the results of a study concerning the contribution of genre awareness and reading habits towards students' reading comprehension. It is geared towards confirming whether genre awareness and reading habits contribute to reading comprehension. Results of the study suggest that good genre awareness and good reading habits can help students develop good reading comprehension. Thus, the findings of the previous studies cited in this article are confirmed. In addition to these findings, this study revealed the extent to which genre awareness and reading habits 
contribute partially and simultaneously to reading comprehension. Considering the results, English teachers are recommended to reflect on what has been elaborated in the paper to help students improve their genre awareness and cultivate good reading habits. As for future researchers whose field of interest is in genre awareness, reading habits, and reading comprehension, it is suggested that they attempt to find what elements of genre awareness and reading habits have a dominant contribution to reading comprehension. Another suggestion for future research deals with the research design. This study is completely quantitative and did not involve qualitative data. It is recommended for future research to employ a mixed-method, involving indepth interviews with EFL teachers and some groups of students that will enrich the study. Also, viewing the phenomenon of genre awareness, reading habit, and reading comprehension from the perspective of sociocultural, socioeconomic and sociopolitical contexts of the students will provide new information in the area of EFL teaching in Indonesia as one of the non-English speaking countries. A qualitative study focusing on EFL teachers' strategy in developing students' genre awareness is also appealing to deeply investigate the teachers' best practices.

\section{ACKNOWLEDGEMENTS}

I would like to thank Professor Bambang Yudi Cahyono and Professor Yazid Basthomi as the validators of the tests used in this study, and PNPB Universitas Negeri Malang as the sponsor of this study.

\section{REFERENCES}

Anderson, M., \& Anderson, K. (2003). Text types in English. Macmillan Education Australia Pty Ltd.

Andriyani, M., Arbain., \& Ariyanti. (2019). The correlation between student's reading habit in English and students' reading comprehension ability. BORJU: Borneo Educational Journal, l(1), 15-21 https://doi.org/10.24903/bej.v1i1.255

Azizah, A., \& Fahriany, F. (2017). The Relationships between students' gext genre awareness and critical thinking disposition with their reading comprehension. Journal of Education in Muslim Society, 4(1), 104-113.

Brown, H. D. (2001). Teaching by principles. An interactive approach to language pedagogy. Addison Wesley Longman, Inc.

Chettri, K., \& Rout, S. K. (2013). Reading habits An overview. IOSR Journal of Humanities and Social Science (IOSR-JHSS), 14(6), 13-17.

Devitt, A. J. (2004). Writing genres. Southern Illinois University Press.
Eriksson, A., \& M. Gustafsson. (2008). Tackling transfer and transferability: ESP/EAP design for learning beyond templates. In I. FortanetGomez \& C. Räisänen (Eds.), ESP in European higher education: Integrating language and content (pp. 117-142). John Benjamins Publishing Co.

Francis, H., \& S. Hallam. (2000). Genre effects on higher education students' texts reading for understanding. Higher Education, 39(3), 279296.

Galea, M. (2005). English for a better life. Pakar Raya

Gaona, J. C. G. (2011). Relationship between reading habits, university library and academic performance in a sample of psychology students, Superior Journal, XL(I)(157), 59-60

Garner, R. (1987). Metacognition and reading comprehension. Ablex Publishing Corporation.

Ghasemi, A., \& Zahediasl, S. (2012). Normality test for statistical analysis: A guide for nonstatisticians. International Journal of Endocrinology Metabolism, 10(2), 486-489

Grabe, W. (2012). Current developments in second language reading research. TESOL Quarterly, 25(3), 375-406. https://doi.org/10.2307/3586977

Hansen, J. M. (2018). Genre analysis report. An English language arts curriculum framework for American public schools.

Hidayah, N. (2014). The correlation between reading habit in English and reading comprehension at second semester of IAIN Tulungagung academic year 2012/2014. [Unpublished master's thesis]. IAIN Tulungagung.

Hyland, K. (2003). Second language writing. Cambridge University Press.

Hyon, S. (1996). Genre in three traditions: Implications for ESL. TESOL Quaterly. 30(4), 693-722. https://doi.org/10.2307/3587930

Hyons, S. (2002). Genre and ESL reading: A classroom study. In Ann M. Johns (Ed.), Genre in the classroom: Multiple perspectives (pp. 121-141). Lawrence Erlbaum Associates.

Johns, A. M. (2008). Genre awareness for the novice academic student: An ongoing quest. Language Teaching, 41(2), 237-252. https://doi.org/10.1017/S0261444807004892

Iskandar, W., \& Sunendar, A. (2017). Students' reading habit at Azmania Boarding School. Edupedia, 3(1).

Kalali, N. N., \& Pishkar, K. (2015). The effect of genre-based teaching on Iranian EFL learners' L2 reading comprehension. Journal of Applied Linguistics and Language Research, 2(7), 123137.

Karbelaei, A. R., \& Hajezi, M. (2015). The effect of genre-based instruction on reading comprehension among EFL Iranian learners. 
Journal of Language and Literature, 6(1), 253261. https://doi.org/10.7813/j1l.2015/6-1/46

Martin, J. R. (1992). English text: System and structure. John Benjamins.

Miller, C. R. (1984). Genre as social action. Quarterly Journal of Speech, 70(2), 151-167. https://doi.org/10.1080/00335638409383686

Molotja, T. W., \& Themane, M. (2018). Enhancing learners' reading habits through reading bags at secondary schools. Journal of the Reading Association of South Africa, 9(1), 185. https://doi.org/10.4102/rw.v9i1.185

Mu'awana, M. (2018). The correlation between students' reading habits and their reading comprehension at the eleventh grade of Islamic High School Al Jauharen Jambi [Unpublished master's thesis]. Sulthan Thaha Saifuddin Jambi.

Muawanah, S. (2014). The relationship between students' reading habit and their reading comprehension [Unpublished master's thesis]. UIN Jakarta.

Nam, K. H. (2014). ELL high school students' metacognitive awareness of reading strategy use and reading proficiency. The Electronic Journal for English as a Second Language, 18(1), 1-16.

Neal, D. T., Wood, W., \& Shen, L. (2006). Computer technology and college students' reading habits. Chia-Nan Annual Bulletin, 32, 559-572.

Nuttall, C. (1982). Teaching reading skills in a foreign language. Richard Clay Ltd, Bungay, Suffolk.

Parmawati, A. (2018). The study correlation between reading habit and pronunciation ability at the second grade students of IKIP Siliwangi. ELTIN JOURNAL Journal of English Language Teaching in Indonesia, 6(1), 46. http://dx.doi.org/10.22460/eltin.v6i1.p4652

Richards, J., Platt, J., \& Weber, H. (1985). Longman dictionary of applied linguistics. Longman.

Rowley-Jolivet, E., \& Carter-Thomas, S. (2005). Genre awareness and rhetorical appropriacy: Manipulation of information structure by NS and NNS scientists in the international conference setting. English for Specific Purposes, 24(1), 41-64. http://dx.doi.org/10.1016/j.esp.2003.09.003

Rozimela, Y. (2014). The students' genre awareness and their reading comprehension of different text types. International Journal of Asian Social Science, 4(4), 460-469

Rustania, F., Maryadi, M., \& Hikmat, M. H. (2019). The contribution of students' reading habit, students' reading strategy, and students' motivation toward reading achievement [Unpublished master's thesis]. Universitas Muhammadiyah Surakarta
Sakinah, S. (2018). The correlation between students' reading habits and reading achievement in English education study program at Jambi University [Unpublished master's thesis]. Jambi University.

Sari, R. A. (2017). Students' perception toward their reading difficulties of different genres. Lingua Didaktika, 7(1), 45-57. https://doi.org/10.24036/ld.v7i1.3531

Sawangsamutchai, Y., \& Rattanavick, S. (2016). A comparison of seventh grade Thai students' reading comprehension and motivation to read English through applied instruction based on the genre-based approach and the teacher's manual. English Language Teaching, 9(4), 5463. http://dx.doi.org/10.5539/elt.v9n4p54

Suhana, A., \& Haryudin, A. (2017). The effects of reading habit towards students' reading comprehension at private senior high school in Purwakarta. ELTIN Journal, 5(II), 57-70. https://doi.org/10.22460/eltin.v5i2.p57-70

Suharyadi, S. (2021). Genre and text type. In Hayati, N., Suharyadi, Andreani, S. \& Astuti, P.A. (Eds.), The changing face of ELT: A festschrift for Prof. Ali Saukah and Prof. M. Adnan Latief (pp. 135-147). UM Press.

Swales, J. M. (2009). Worlds of genre. In Bazerman, C., Bonini, A. and Fiqueiredo, D (eds). Genre in a changing world (pp. 3-16). Parlor Press.

Swales, J. M. (1990). Genre analysis: English in academic and research settings. Cambridge University Press.

Taylor, D. S. (1985). Teaching reading for comprehension in the context of English as a second or foreign language. British Journal of Language Teaching, 23(2), 163-68.

To, K. K., \& Pang, M. F. (2019). A study of variation theory to enhance students' genre awareness and learning of genre features. International Journal for Lesson and Learning Studies, 8(3), 183-195. https://doi.org/10.1108/ijlls-10-2018-0070

Toledo, P. F. (2005). Genre analysis and reading of English as a Foreign Language: Genre schemata beyond text typologies. Journal of Pragmatics, 37(7), 1059-1079. https://doi.org/10.1016/j.pragma.2005.01.002

Trabasso, T. (1981). On the making of inferences during reading and their assessment. In J. T. Guthrie (Ed.), Comprehension and teaching: Research reviews. (pp. 56-76). Newark, Delaware: International Reading Association.

Vollmer, G. (2018). Genre awareness and analysis: A strategic tool for language learning [Power Point slides]. Berkeley Language Center. Retrieved from http://blc.berkeley.edu/wpcontent/uploads/2018/01/Genre-AwarenessVollmer-3.2018.pdf 
Wahyudi, A. (2016). The correlation between reading habit and reading comprehension achievement of 12th grade students of MA PP Qodratulloh Langkan. Proceedings of the 2nd SULE - IC 2016, FKIP-Universitas Sriwijaya

Wulandari, E. (2016). Developing curriculum and tasks for teaching reading. Journal of English and Education, 6(2), 23-35. https://doi.org/10.20885/jee.vol6.iss2.art3

Xu, X., \& Li, X. (2018). Teaching academic writing through a process-genre approach: A pedagogical exploration of an EAP program in China. The Electronic Journal for English as a Second Language, 22(2), 1-21

Yayli, D. (2011). From genre awareness to crossgenre awareness: A study in an EFL context. Journal of English for Academic Purposes, 10(2011), 121-129. https://doi.org/10.1016/J.JEAP.2011.02.001

Zwiers, J. (2004). Building reading comprehension habits in grade 6-12. International Reading Association. 